\title{
PENGARUH PELAKSANAAN KENDURI SKO (PESTA PANEN) TERHADAP PEREKONOMIAN DAN KEPERCAYAAN MASYARAKAT MASYARAKAT KERINCI, PROVINSI JAMBI
}

\author{
Yolla Ramadani $^{1}{ }^{2}$, Astrid Qommaneeci ${ }^{3}$
}

\begin{abstract}
This article is the result of a research conducted aiming to know the influence of Kenduri Sko implementation (harvest feast) on the economy and the belief of Kerinci community. This research uses descriptive qualitative method where data collected by observation, interview and documentation study. The results show that Kenduri sko (harvest feast) has been passed down from generation to generation by the people of Kerinci. The series of activities undertaken in Kenduri Sko including art and cultural performances, such as Tarei Asyeik to invite ancestral spirits, crowning custom titles, cleansing of heirlooms as well as thanksgiving for abundant harvests. Kenduri Sko is an expression of gratitude to Allah SWT who has given sustenance and therefore people begged or prayed in order to multiply their income through the harvest of rice in the upcoming year. This ceremony in addition to providing benefits to Kerinci people and express gratitude to God Almighty, also gives influence in the social field towards the existence of social bonds that exist between the community. In the economic field, Kenduri Sko has affected the income of Kerinci area. In the field of religion, Kenduri Sko gives influence to people's harmony life, especially among Kerinci people who are Muslims. This is corresponds to Islamic teaching where we need to help each other and foster a sense of brotherhood among each other.
\end{abstract}

\section{Keywords : Economy and Belief, Harvest Feast, Kenduri Sko, Kerinci Region}

\section{Abstrak}

Artikel ini merupakan hasil penelitian yang dilakukan dengan tujuan untuk mengetahui pengaruh pelaksanaan kenduri sko (pesta panen) terhadap perekonomian dan kepercayaan masyarakat Kerinci. Penelitian ini menggunakan metode kualitatif deskriptif dimana data dikumpulkan dengan observasi, wawancara dan studi dokumentasi. Hasil penelitian menunjukkan bahwa Kenduri sko (pesta panen) telah dilaksanakan turun temurun dari generasi ke generasi oleh masyarakat Kerinci. Rangkaian kegiatan yang dilaksanakan dalam kenduri sko diantaranya pergelaran seni budaya, Tarei Asyeik untuk mengundang roh-roh nenek moyang, penobatan gelar adat, pembersihan benda-benda pusaka dan syukuran atas hasil panen yang melimpah. Kenduri Sko adalah ungkapan rasa syukur kepada Allah SWT yang telah memberikan rizki dan memohon untuk dilipatgandakan pendapatan mereka lewat hasil panen padi untuk tahun yang akan datang. Upacara ini selain memberi manfaat

\footnotetext{
${ }^{1}$ Dosen STIE Sakti Alam Kerinci, Sungai Penuh, Jambi

${ }^{2}$ Korespondensi Penulis, email: yolla_ramadani@yahoo.com

${ }^{3}$ Dosen STIE Sakti Alam Kerinci, Sungai Penuh, Jambi

DOI: 10.25077/jantro.v20.n1.p71-83.2018

JANTRO ISSN: 2355-5963 (Online)

under Lisensi Creative Commons Atribusi-BerbagiSerupa 4.0 Internasional
} 
terhadap masyarakat Kerinci untuk menambah rasa syukur kepada Tuhan Yang Maha Esa juga memberikan pengaruh dalam bidang sosial, yang mana Kenduri Sko memberikan pengaruh pada adanya ikatan sosial yang terjalin antara masyarakat. Dalam bidang ekonomi, Kenduri Sko berpengaruh pada pendapatan daerah Kerinci. Dalam bidang agama, Kenduri Sko memberi pengaruh pada kehidupan kerukunan umat khususnya masyarakat Kerinci yang beragama Islam. Dimana Islam mengajarkan untuk saling tolong menolong dan memupuk rasa persaudaraan antar sesamanya.

Kata-kata Kunci: E konomi dan Kepercayaan, Pesta Panen, Kenduri SKO, Kerinci

\section{A. PENDAHULUAN}

$\mathrm{S}$ etiap masyarakat mempunyai kebuda yaan yang terbentuk oleh sistem kepercayaan, sistem religi yang sebagian besar dikenal sebagai agama. Sistem kepercayaan bertujuan agar masya rakat dapat memposisikan hakikat manusia sebagai bagian integral dari kebudayaan. Sistem yang mengatur kehidupan masya rakat, yang sangat menentukan bagaimana masyarakat melihat sesuatu, bagaimana memandang hal itu, bagaimana menilai sesuatu dan harapan masyarakat tentang situasi tertentu, pengalaman dan kehidupan pada umumnya (Bustanuddin, $2006: 47$ )

Sistem kepercayaan yang dianut oleh setiap masyarakat sedikit banyaknya akan mempengaruhi tingkah laku maupun kebiasaan masyarakat tersebut dalam berbagai hal, salah satunya sistem ekonomi dan mata pencaharian masyarakat. Keadaan alam pemukiman suku Kerinci berupa dataran tinggi,dengan ketinggian antara $900-1.500$. M.Dpl dengan curah hujan rata rata berkisar $3.000-4.000 . \mathrm{M} 3$ pertahun dengan suhu maksimum 28 Derajat Celcius, letak pemukiman penduduk berada dibawah lereng gunung dan diatas areal persawahan sehingga masyarakat sebagian besar bertahan hidup dengan bertani (Benyamin : http://www.kerincikab. go.id)[Accesed 21 Juli 2017].

Masyarakat Kerinci sejak ratusan tahun telah memiliki pola tatanan kehidupan kemasyarakatan yang beradat. Adat Kerinci telah ada sejak keberadaan suku bangsa Kerinci menghuni alam Kerinci, dan adat itu merupakan suatu norma hukum yang tumbuh dan berkembang seirama dengan dinamika gerakan masyarakat dengan kebutuhannya. Adat itu mengatur kehidupan manusia dalam hubungannya dengan manusia, kehidupan manusia dengan lingkungannya, dan bahkan juga mengatur kehidupan manusia dengan alam gaib.

Di Kabupaten Kerinci kepercayan masya rakat terhadap hasil panen dilakukan dengan melaksanakan pesta rakyat yang disebut dengan "kenduri sko". Hal ini bertujuan untuk mensyukuri hasil panen yang berlimpah. Kenduri ini dilakukan setiap tahunnya di tiap-tiap daerah yang ada di Kabupaten Kerinci. Kenduri sko masih dilaksanakan sampai saat ini dikarenakan adanya kepercayaan masyarakat bahwa jika tidak dilaksanakan maka roh-roh nenek moyang akan murka dan masyarakat akan mengalami gagal panen. Oleh karea itu tujuan dilaksanakan kenduri sko adalah masyarakat berharap agar hasil panennya terus berlimpah. Masyarakat percaya bahwa jika tidak dilakukan kenduri sko maka akan terjadi penurunan pada hasil panen. Hal ini akan berpengaruh terhadap perekonomian masyarakat. Dengan adanya kenduri sko tersebut dapat menjalin hubungan silahtu rahmi yang baik antara masyarakat sekitar. Kekompakkan dalam gotong royong tampak jelas manakala ada hajatan-hajatan. Berbagai fungsi dan tujuan kenduri sko dapat mempengaruhi pendapatan masya rakat sekitar dengan adanya kenduri sko, karena masyarakat sekitar dapat berperan serta dalam kenduri sko sehingga dapat meningkatkan pendapatannya, walaupun kenduri sko hanya dilakukan setahun sekali tetapi hal itu membawa berkah bagi warga sekitar. 
Dalam proses ritual atau acara-acara adat dan hajatan di kampung-kampung tidak sedikit biaya yang dibutuhkan. Karena kebiasaan yang terjadi di masyarakat adat setiap syukuran harus mengundang seluruh anggota keluarga dan jumlahnya cukup banyak dan yang dijamu dengan aneka ragam makanan mulai dari jenis tradisional hingga jenis kue modern. Pada acara ini pos pembiayaan yang punya hajatan sangat tinggi mulai dari persiapan acara dimana warga Desa harus menyiapkan dana untuk kenduri sko. Setiap warga harus menyum bang sesuai dengan hasil kesepakatan musyawarah pemukan adat yang telah disepakati bersama.

Kenduri sko merupakan kepercayaan yang wajib dilakukan oleh mayarakat Kerinci, secara tidak langsung tradisi ini membutuhkan dana yang besar untuk karena dalam rangkaian acara ini juga dilakukan pengukuhan gelar adat kepada ninik mamak, tuo teganai, dan tokoh-tokoh masyarkat, serta adat. Dalam rangkaian kenduri sko dilaksanakan upara ritual menurunkan dan membersihkan benda benda pusaka antara lain Keris, Pedang, Tombak dan piagam-piagam. Selain itu, dalam acara ini juga ditampilkan pertunjukan kesenian anak negeri (masyarakat desa) pada seni dan budaya dalam pesta kenduri sko biasanya diadakan selama tujuh hari tujuh malam, selama-lamanya $3-7$ hari. Kesenian yang ditampilkan antara lain tari iyo-iyo, rangguk, asyik, pencak silat dan pertunjukan lain sesuai adat setempat seperti batauh di Lempur. Upacara lain sajian sakti (jambe), nyerau, tutur tabano dan kegiatan lain yang berhubungan dengan spiritual masyarakat Kerinci. Lalu ada pemberian makan para hulubalang sakti (roh-roh sakti nenek moyang, harimau gaib dan makhluk halus) yang diambil dari bagian-bagian utama kerbau seperti otak, jantung, hati, limpo dan lain-lain dikemas berupa sajian. Sajian ini ditempatkan pada pulo negeri (menhir dusun/desa) atau pada suatu tempat sakral diluar dusun/desa. Kemudian upacara penurunan pusakapusaka negeri ataupun suku dari tempat penyimpanan diatas tulok bahae, tulak balaho (loteng tinggi), guna dibersihkan dengan ramuan bermacam-macam limau yang dinamai mandai atau malimo puseko.

Rangkaian aktivitas-aktivitas di atas tentunya menghabiskan dana yang kurang lebih Rp. 300.000.000,00 setiap tahunnya. Dana yang besar ini tentunya berpengaruh pada ekonomi masyarakat, masyarakat akan mengeluarkan dana dalam jumlah yang besar, tentunya menurunkan ekonomi masyarakat, namun tradisi ini tetap bertahan tentunya memiliki dampak positif bagi ekonomi masyarakat.

Kenduri sko sangat ditunggu oleh masyarakat sekitar dan masyarakat dari daerah lainnya karena pelaksanaan kenduri sko yang cukup unik. Hal ini tentunya mengundang perhatian wisatawan untuk ikut serta hadir dalam pelaksanaan kenduri sko. Kehadiran wisatawan juga berpengaruh pada pendapatan masyarakat. Masyarakat dapat mempromosikan budayanya dan menjual hasil panennya dan kreativitas desanya. Maka dari itu peneliti ingin melihat dampak secara ekonomi dari bertahannya tradisi kenduri sko (pesta panen) pada masyarakat Kerinci, Provinsi Jambi. Berdasarkan latar belakang permasalahan di atas, penelitian ini bertujuan untuk melihat sejauh mana pengaruh pelaksanaan kenduri sko (pesta panen) terhadap tingkat perekonomian dan kepercayaan masyarakat Kerinci, Provinsi Jambi. Penelitian ini juga diharapkan dapat meberikan manfaat untuk pengembangan khasanah ilmu pengetahuan sosial khususnya dalam bidang kajian budaya. Selain itu, dapat memberikan pengetahuan dan wawasan kepada pembaca mengenai salah satu budaya bangsa Indonesia yang masih terjaga keberadaannya oleh masyarakat itu sendiri. Secara praktis penelitian ini memberikan kesempatan bagi peneliti-peneliti lain untuk memperdalam kajian mengenai penelitian budaya kenduri sko.

\section{B. METODE PENELITIAN}

okasi penelitian ini adalah Kabupaten Kerinci, Provinsi Jambi. lbu kota Kabupaten terletak di Kecamatan Siulak. Kabupaten Kerinci memiliki luas $3.355,27 \mathrm{~km}^{2}$ terdiri atas 16 kecamatan. Hampir 90 \% Masyarakat Kerinci masih 
eksis dalam pelaksanaan kenduri sko (pesta panen). Penelitian ini menggunakan metode kualitatif deskriptif dimana data dikumpulkan dengan observasi (pengamatan terlibat), wawancara dan studi dokumentasi. Analisis data dalam penelitian kualitatif dilakukan pada saat pengumpulan data berlangsung, dan setelah selesai pengumpulan data dalam periode tertentu. Proses analisis data berlansung terus menerus selama penelitian dilakukan dengan menggunakan model analisis interaktif dari Miles dan Huberman terdapat dalam Bungin (2005:69), dalam hubungan ini meliputi reduksi data, penyajian data dan penarikan kesimpulan.

\section{HASIL DAN PEMBAHASAN}

umlah penduduk Kabupaten Kerinci per 31 Desember 2010 sebesar 311.354 jiwa, yang terdiri dari 154.227 jiwa penduduk laki-laki dan 157.127 jiwa penduduk perempuan dengan ratio 98 Kepadatan penduduk tahun 2006 sebesar 74 jiwa per km2. Berdasarkan Kerinci Dalam Angka Tahun 2010, penduduk Kabupaten Kerinci berjumlah 308.785 jiwa. Ini berarti pertumbuhan penduduk Kabupaten Kerinci bertambah sebesar 0,83\% pertahun. Sebagian besar bekerja pada sektor pertanian dan perkebunan. Lahan-lahan pertanian dan perkebunan menghasilkan beraneka ragam produk seperti, sayursayuran, palawija, buah-buahan, dan lain sebagainya. Pertanian pada sawah merupakan hamparan yang paling luas memberi keindahan alam yang mempesona disaat musim panen tiba. Selain itu produk perkebunan seperti kayu manis (Cassiavera), kopi dan teh merupakan produk dengan kwalitas ekspor. Tujuan Ekspor meliputi Negara Eropa, Amerika, Arab dan Asia Timur. Kondisi pertanian dan perkebunan ini merupakan obyek agro wisata yang menarik khas dataran tinggi Kerinci (Alimin, dkk, 2006 : 67)

Berdasarkan data di atas dapat dilihat bahwa sebagian besar masyarakat Kerinci bekerja di sektor pertanian. Hal ini didukung oleh kondisi alam yang sangat subur. Jumlah petani yang begitu besar dibanding mata pencaharian lain, membuat budaya kenduri sko menjadi hal yang sangat melekat dalam kehidupan sosial masyarakat Kerinci, karena pada dasarnya kenduri sko merupakan budaya yang dilaksanakan oleh masyarakat untuk merayakan hasil panen yang melimpah. Masyarakat memerlukan sebuah keyakinan bahwa mereka akan selalu diberi kelimpahan dan kemakmuran. Upacara syukuran tersebut nampak sebagai upacara yang wajar serta lumrah dilakukan.

\section{Kehidupan Sosial Budaya Masyarakat Kerinci}

Suku Kerinci adalah suku asli di provinsi Jambi. Suku Kerinci merupakan suku melayu tertua yang ada di nusantara, memiliki beragam peninggalan kebudayaan masa lampau hingga peninggalan sejarah masa kini. Suku Kerinci tidak hanya sebuah kelompok masyarakat yang mendiami wilayah Kerinci tapi juga masyarakat tradisional yang hidup erat dengan adat istiadat dan budaya warisan leluhur.

Bumi alam Kerinci juga memiliki berbagai peninggalan seni, salah satu buktinya adalah upacara adat yang kini masih mampu bertahan pada era teknologi tinggi dan peradaban modern. Mereka masih mempertahankan kebudayaan warisan ne nek moyang sampai saat ini. Walaupun mayoritas masyarakatnya telah memeluk agama Islam, masyarakat suku kerinci masih melakukan ritual-ritual adat seperti halnya nenek moyang mereka.

Masyarakat adat Kerinci mengenal sistem sko tiga takah. Sko tiga takah adalah bentuk struktur pelapisan sosial yang terdapat pada masyarakat Suku Kerinci. Sistem sko tiga takah itu diantaranya adalah Depati atau setingkat Depati, Permenti atau Ninik Mamak dan Tengganai atau anak jantan yang menjadi dasar kepemimpinan secara adat. Dalam kehidupan masyarakat Kerinci dikenal sistem sko tiga takah (tingkatan). Pengertian sko berasal dari kata 'saka" berarti, keluarga atau nenek moyang dari pihak ibu. Sko tiga takah merupakan bentuk struktur pelapisan sosial yang terdapat pada masyarakat Kerinci. Sistem sko tiga takah itu dalah Depati atau setingkat Depati, Permenti atau Ninik 
Mamak, dan Tengganai atau anak jantan. Untuk jadi Depati atau Ninik Mamak dipilh oleh masyarakat anak jantan yang memenuhi persyaratan, karena prinsip adat Kerinci gelar sko yang melekat pada diri seseorang memiliki sifat kawi (kuat). Depati dan Ninik Mamak adalah simbol tertinggi pada struktur lapisan sosial masyarakat Kerinci, kedudukan dan fungsi yang melekat berupa gelar sko menjadikan ia bangsawan jabatan pada sistem" sko tiga takah". Sko adalah gelar pusaka turun temurun yang disandang oleh raja adat (kepala suku).

Pemangku adat dalam menjalankan tugas memberi keizinan ajun-arah bagi kegiatan anak-kemenakannya, ada tiga perkara yang tidak boleh dianju-diarah oleh Depati Ninik Mamak, yaitu:

- Jeluang di tengah negeri:ialah ajunarah yang telah diberikan kepada seseorang, tidak boleh diberikan kepada orang lain.Tetapi ada batas waktunya sesuai dengan aturan adat setempat, kemudian arah digulung dan dikembali kepada hak negeri/dusun wewenang Depati Ninik Mamak.

- Kayu ara empang berakar,ialah jika rumah atau lumbung padi/ rangkiang yang telah rusak, tetapi masih terdapat tanda berdirinya walaupun sebatang tonggak.

- Galung terlentang, cocok tanam yang letaknya diluar parit bersudut empat/negeri, yang sudah dimiliki atau dipelihara seseorang maupun kaum, misalnya pendam pekuburan dan belukar yang sudah tidak digarap lagi.

\section{Pelaksanaan Kenduri Sko (Pesta Panen)}

Kenduri Sko merupakan kenduri adat yang dilaksanakan oleh masyarakat setelah panen. Kenduri ini dilaksanakan sebagai wujud rasa syukur atas hasil panen yang melimpah. Kenduri ini juga dilaksanakan bersamaan dengan pengangkatan gelar kepemimpinan Sko yang tigo takah. Dari sudut ilmu antropologi kebudayaan acara kenduri Sko memiliki makna siklus kehi dupan yang bersifat universal. Upacara kenduri sko hanya dilakukan pada desa DOI: 10.25077/jantro.v20.n1.p71-83.2018

JANTRO ISSN: 2355-5963 (Online)

under Lisensi Creative Commons Atribusi-BerbagiSerupa 4.0 Internasional pesekutuan adat atau masyarakat adat dari dusun asal desa-desa yang memiliki sejarah tetua adat depati ninik mamak dan juga memiliki benda-benda pusaka. Kenduri Sko merupakan kenduri adat yang terdiri dari beberapa rangkaian kegiatan diantaranya pergelaran seni budaya, penobatan gelar adat, pembersihan benda-benda pusaka dan syukuran atas hasil panen yang melimpah. Rangkaian kegiatan ini memakan waktu biasanya 3-4 hari.

Sesuai dengan ketentuan adat yang telah diwarisan secara turun-temurun, lazimnya untuk dapat menyandang gelar Depati atau setingkat Depati ada tiga ketentuan pokok yang mesti dilaksanakan :

- Menghanguskan beras seratus kerbau seekor, yaitu kenduri adat, dengan memotong seekor kerbau dan memasak beras bilangan seratus gantang dalam suatu upacara adat Kerinci.

- Jadi di atas bangkai atau kubur, artinya mengganti Depati yang telah wafat dengan Emas semas yaitu memberi uang penaik sebagai persyaratan.

- Hilang bersilang atau dipilih berdasarkan musyawarah Depati Ninik Mamak, yaitu dipinjam sementara seseorang dari kaumnya sebagai penungkat menggantikan Depati.

Depati tersebut hilang atau dianggap hilang, yaitu:

- Yang wafat di rantau orang.

- Tidak dapat menjalankan tugas karena sesuatu sebab, misalnya tempat tinggal yang bersangkutan jauh sehari perjalanan kaki maka boleh dikembarkan. Depati peng ganti ini sifatnya, jika dekat ia kebayang raja, jika jauh ia sebagai ganti raja.

- Dipecat karena melakukan kesala han adat, hanyut di pelayang jatuh di pemanjat. Yang memecat rapatrapi anak jantan anak betino serta depati ninik mamak dalam negeri yang bersangkutan.

- Ketuaan atau keuzuran, gunung yang tinggi tidak terdaki lurah yang 
dalam tidak terturun, yaitu sudah kekurangan syarat menjadi depati.

Untuk menjadi ninik mamak atau setingkat ninik mamak ketentuannya hampir sama dengan depati, yaitu:

- Mengangus beras dua puluh kambing seekor atau kenduri adat, dengan memotong seekor kambing dan memasak beras bilangan dua puluh gantang dalam suatu upacara adat Kerinci.
- Naik di atas kubur dengan menga nguskan 'mas sekundi' atau uang penaik sebagai persyaratan adat.

- Hilang bersilang yaitu, disilih menjadi penungkat yang ketentuannya sama dengan jadi Depati.



Depati dengan Pakaian Adat Kerinci

\section{Waktu dan Tempat Pelaksanaan Kenduri Sko}

Waktu pelaksanaan di setiap desa berbeda-beda. Adanya sekelompok kaum/ desa yang melaksanakan nya satu kali setahun, satu kali dalam tiga tahun bahkan sampai satu kali setahun tergantung kesepakatan yang telah dimusyawarahkan. Ini terjadi karena seiring berjalannya waktu dan kebutuhan masyarakat yang semakin meningkat. Sesuai dengan ungkapan adat nya "kerbau seekor dan beras seratus" yang harus dihabiskan untuk upacara ini yang tentu sulit untuk diusahakan oleh masya rakat. Kegiatan ini biasanya dilaksanakan setelah panen terutama panen hasil sawah yang pada awalnya dilakukan untuk tujuan meningkatkan rasa kebersamaan antar sesama masyarakat yang memanen. Untuk pemeilihan hari yang akan digunakan untuk pelaksanaan kenduri Sko itu sendiri tidak ada syarat tertentu. Untuk menentukan hari biasanya daerah-daerah tersebut hanya melakukan kesepakatan bersama. Hari yang ditentukan biasanya tidak hanya satu, karena pelaksanaan kenduri sko ini biasanya membutuhkan 3-4 hari.
Di alam Kerinci tradisi "Kenduri Sko"masih mampu bertahan ditengah pesatnya kemajuan dan perubahan zaman. Bisa kita lihat bahwa Masyarakat Suku Kerinci sangat menghargai para leluhur, bahkan benda benda karya cipta termasuk benda benda budaya telah mereka wariskan dalam bentuk Pusaka dan pada setiap periode tertentu benda pusaka itu di turunkan, dibersihkan dan di perlihatkan kepada segenap anak jantan dan anak betino yang ada di dalam Luhah masing masing. Pelaksanaan Kenduri Sko diadakan di tiap-tiap desa yang berbeda beda. Biasanya rangkaian kenduri sko akan diadakan di balai-balai adat desa tersebut.

\section{Persiapan Kegiatan}

Kenduri sko sebagai bentuk rasa syukur masyarakat dilaksanakan dengan persiapan yang lama. Biaya yang lumayan besar menuntut masyarakat harus mempersiapkan biaya jauh hari sebelum pelaksanaan. Harga barang yang semakin meningkat disertai dengan perkembangan zaman menuntut masyarakat untuk benar-benar mengatur segala kebutuhan sehari-hari dengan penuh

DOI: 10.25077/jantro.v20.n1.p71-83.2018

JANTRO ISSN: 2355-5963 (Online)

under Lisensi Creative Commons Atribusi-BerbagiSerupa 4.0 Internasional 
perhitungan. Hal ini tidak mengurangi semangat masyarakat untuk melaksanakan kenduri sko. Untuk mengatasi permasalahan biaya yang besar, masyarakat mengatasinya dengan mengadakan tabungan keluarga yang mereka lakukan setiap bulannya untuk meringankan beban biaya pelaksanaan kenduri sko. Jadi biaya yang besar tidak begitu terasa berat karna telah ditabung jauh hari.
Persiapan pertama yang dilakukan adalah pemasangan umbul-umbul atau bendera warna-warni yang dipasang di sekitar tempat upacara, bendera merah putih berbentuk segitiga siku-siku berukuran besar (Karamtang) yang dipasang ditempat terbuka pada ketinggian mencapai 30 meter yang puncaknya digantunngkan Tanduk kerbau. Bendera ini merupakan lambang atau pun simbol pemberitahuan bahwa akan diadakan kenduri sko pada daerah tersebut.

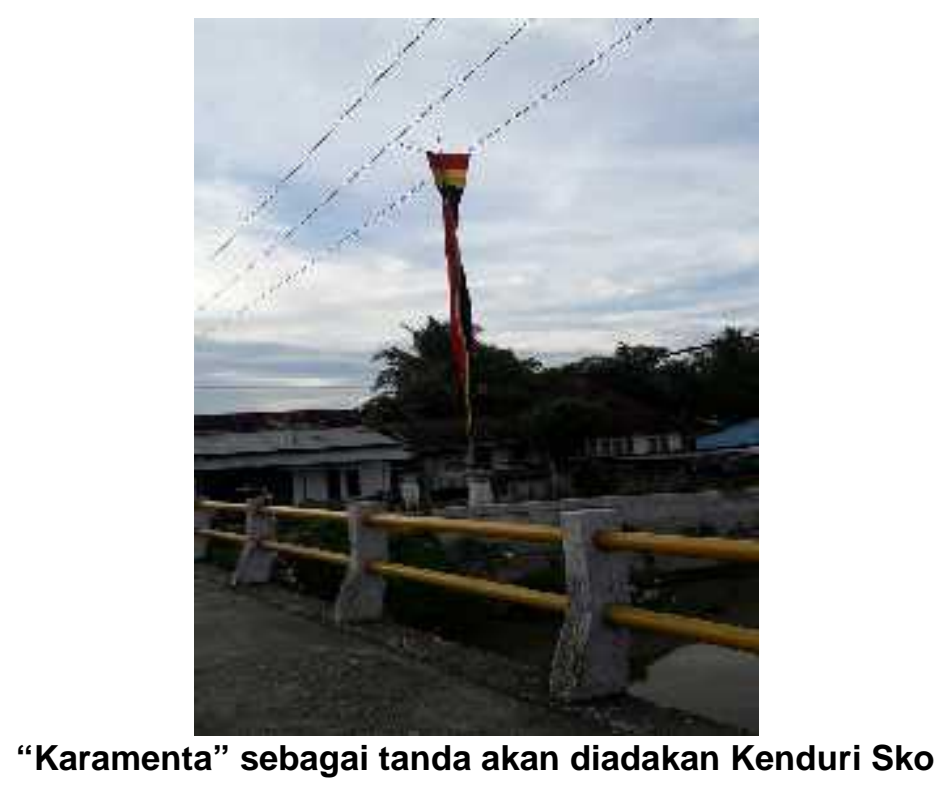

Persiapan pelaksanaan kenduri sko dilakukan oleh masing-masing keluarga di daerah yang akan melaksanakan kenduri sko. Persiapan yang dilakukan oleh masingmasing keluarga adalah mempersiapkan hidangan yang akan disuguhkan kepada para tamu yang diundang nantinya. Biasanya yang diundang datang pada pelaksanaan kenduri sko adalah kerabat dekat, teman-teman yang tinggal di daerah lain, pejabat pemerintahan dan lain sebagainya. Biasanya mereka diundang secara lisan saat bertemu di jalan, di pasar, ataupun di tempat kerja. Namun seiiring dengan perkembangan zaman, banyak pula yang diundang melalui telpon genggam.

Sasaran undangan utama adalah kerabat dan sanak saudara. Mereka yang diundang akan datang untuk bersilahturahmi dan makan bersama. Makanan tersebut merupakan hidangan yang telah disediakan oleh tuan rumah. Selain makanan yang dihidangkan, tuan rumah juga akan menyiapkan lemang sebagai buah tangan tamu yang datang. Selain persiapan hidangan pada hari pelaksanaan, setiap keluarga juga mengadakan musyawarah untuk menentukan siapa nantinya yang akan diberikan gelar pada kenduri sko. Musyawarah ini biasanya dilaksanakan 2-3 kali sampai menemukan kata mufakat.

\section{Perlengkapan Yang digunakan Da lam Pelaksanaan Kenduri Sko}

Setiap kegiatan dapat berjalan dengan lancar didukung oleh sarana dan prasarana 
yang lengkap. Pelaksanaan Kenduri Sko menggunakan perlengkapan diantaranya :

- Tenda atau Taruk berukuran besar diatas Tanah Mendapo (tempat berlang sungnya Upacara adat Kenduri Sko).

- Umbul-umbul atau Bendera berwarnawarni disekitar tempat upacara.

- Bendera merah putih berbentuk segitiga siku-siku berukuran besar (da lam bahasa Kerinci bendera ini disebut dengan Karamtang). Karamtang ini dipasang ditempat terbuka pada ketinggian mencapai 30 meter. Pada bagian puncaknya digantunngkan Tan duk kerbau. Bendera ini merupakan sebuah isyarat tentang adanya Kenduri Sko dan sekaligus menjadi undangan bagi masyarakat banyak untuk datang menghadiri upara yang sakral itu.

- $\quad$ Pakaian adat, keris, dan tongkat yang dipakai oleh para Pemangku adat.

- Pakaian adat para Dayang (dalam bahasa Kerinci disebut dengan Lita dan Kulok).
- Pedang Hulubalang untuk keperluan Pencak Silat

- $\quad$ Sesajian berupa beras kuning, keme nyan, dan adonan sirih nan sekapur rokok nan sebatang.

- Makanan dirantang dan lemang

- Kerbau/ Sapi

- Gong, gendang dan rebana untuk keperluan kesenian daerah yang akan ditampilkan dalam rangkaina prosesi upacara

\section{Proses Pelaksanaan Kenduri Sko}

Berdasarkan pengamatan peneliti sela ma penelitian dilapangan, kenduri sko dapat diklasifikasikan menjadi tiga rangkaian acara yang berlangsung secara berurutan, yaitu Makan bersama, pembersihan benda-benda pusaka dan penobatan gelar adat. Dalam rangkaian upacara ini semua benda pusaka peninggalan nenek moyang dikeluarkan dari tempat penyimpanannya untuk disucikan atau dibersihkan oleh para kepala adat.

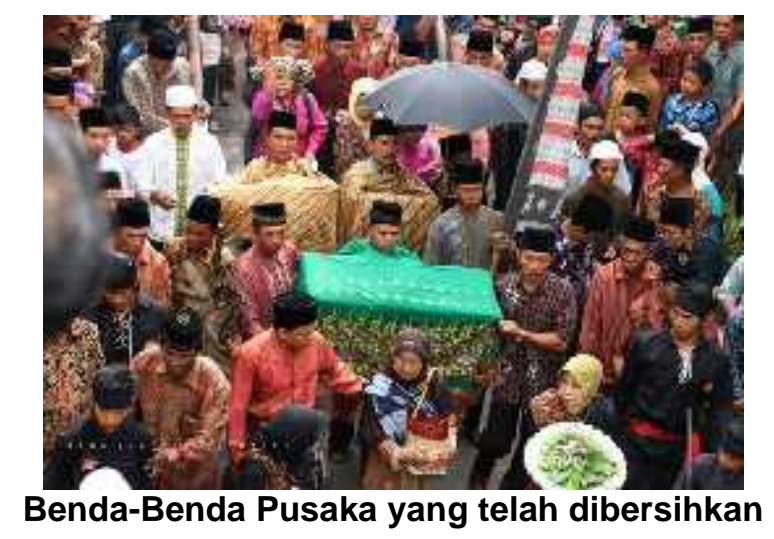

Pelaksanaan kenduri sko biasanya membutuhkan 3-4 hari. Hari pertama biasanya para ibu-ibu akan sibuk memasak menyiapkan makanan dan melemang untuk para tamu yang akan hadir keesokan harinya. Sedangkan Bapak-bapak akan mempersiapkan tarup ataupun tenda yang akan digunakan untuk upacara-upacara adat. Pada hari kedua akan dilanjutkan dengan syukuran (mendo'a) dengan adanya tamu atau anggota kerabat yang diundang mereka dapat mengunjungi setiap rumah dengan waktu yang berbeda. Setiap tamu akan mendapatkan lemang sebagai buah tangan sebagai tanda telah menghadiri acara kenduri sko.

Pada malam harinya, akan diadakan acara pembersihan benda-benda pusaka dari beberapa generasi. Prosesi ini biasanya dilakukan dalam balai-balai adat desa yang mengadakan kenduri sko. Semua masyarakat berkumpul menyaksikan prosesi ini yang biasnya dilaksanakan hingga waktu fajar. Masyarakat akan melakukan tarei asyeik yaitu sebuah tarian magis yang digunakan untuk mengundang roh-roh para

DOI: 10.25077/jantro.v20.n1.p71-83.2018

JANTRO ISSN: 2355-5963 (Online)

under Lisensi Creative Commons Atribusi-BerbagiSerupa 4.0 Internasional 
leluhur guna memberi tahu perayaan yang sedang mereka laksanakan. Tari Asyeik ini dipimpin oleh seorang imam ahli yang nantinya juga mengontrol jika ada salah satu penari yang telah kerasukan ruh leluhur. Prosesi ini sebagai ungkapan rasa syukur masyarakat sekaligus ucapan terima kasih kepada leluhur karena hasil panen yang melimpah. Prosesi ini akan diakhiri dengan upacara sajian sakti (jambe), nyerau, tutur tabano dan kegiatan lain yang berhubungan dengan spiritual masyarakat Kerinci. Lalu ada pemberian makan para hulubalang sakti (roh-roh sakti nenek moyang, harimau gaib dan makhluk halus) yang diambil dari bagian-bagian utama kerbau seperti otak, jantung, hati, limpo dan lain-lain dikemas berupa sajian. Sajian ini ditempatkan pada pulo negeri (menhir dusun/desa) atau pada suatu tempat sakral diluar dusun/desa.

Pada hari yang ketiga, akan diadakan prosesi penobatan gelar-gelar adat kepada tokoh-tokoh yang teah disepakati setiap keluarga. Pelaksanaan Upacara biasanya dilakukan pada pukul 08.00. Pada waktu ini biasanya masyarakat kerinci sudah berkum pul di tanah Mendapo untuk menyaksikan beberapa rangkaian acara yaitu pertunjukan seni Pencak Silat yang merupakan seni bela diri dengan menggunakan dua mata pedang. Tari Persembahan yang merupa kan tari untuk menyerahkan sekapur sirih kepada para petinggi-petinggi daerah yang hadir dan juga menyerahkan sekapur sirih kepada calon Depati, Ngabi, Permanti dan Mangku yang akan dinobatkan menjadi pemangku adat yang baru.

Acara intinya adalah penobatan para pemangku adat. Pada prosesi ini semua calon Depati, Ngabi dan Ninik Mamak dipanggil naik ke atas pentas secara bergantian lima orang sambil dipanggil namanya seraya menjatuhkan Gelar Sko pada para bangsawan tersebut. Tokoh yang terpilih nantinya akan memberikan pidato adat yang disebut deto talitai. Deto talitai ialah rangkaian pidato adat yang disampaikan dalam bahasa berirama, dilakukan sewaktu upacara kenduri sko (adat) dan pengukuhan gelar kebasaran tertua adat atau kepala suku Depati ataupun Ninik Mamak.
Dalam upacara ini para Depati dan Ninik Mamak terpilih memakai pakaian adat khusus yang memilki makna tertentu. Para Depati biasanya memakai seluk, kain sarung lurus dan pakaian berwarna hitam dengan hiasan sulaman benang warna kuning di dada sementara Ninik Mamak memakai Lita, kain sarung miring dan pakaian berwarna hitam dengan hiasan sulaman benang warna kuning di dada. Warna-warna dalam pakaian tersebut mengandung makna khusus seperti misalnya warna hitam yang melambangkan rakyat banyak berarti kekuatan Depati dan Ninik Mamak dan warna kuning yang melambangkan kekuasaan berarti berundang berlembago, artinya Depati dan Ninik Mamak melaksa nakan kekuasaan berdasarkan undangundang dan lembago. Benda-benda pusaka yang telah diturunkan dan dibersihkan, akan dikembalikan ketempat semula oleh para tokoh-tokoh adat yang terpilih.

\section{Pandangan Masyarakat Terhadap Kenduri Sko}

Upacara adat merupakan perbuatan yang sering kali tidak dapat dijelaskan asal mulanya, karena upacara merupakan peninggalan dari para leluhur suatu masyarakat di suatu daerah yang secara terus menerus kegiatan tersebut dilaksa nakan pada waktu dan saat yang sama setiap tahunnya, dari generasi ke generasi sebagai pewarisnya. Menurut Amin Saib, kesan mendasar terhadap penyelenggaraan upacara tradisional yang diselenggarakan oleh warga masyarakat pendukungnya, didasarkan pada segi kepentingan adat. Kedua kepentingan ini saling berpengaruh dan selalu berkaitan (Amin Saib, 1985 : 162). Sesuai pendapat tersebut upacara adat didasarkan atas kepentingan adat dan agama yang tercermin dalam kegiatan upacara yang dalam kegiatan pelaksa naannya memperlihatkan adanya hubungan antara manusia dengan kekuatan ghaib atau Tuhan yang berpengaruh dengan kehidupan manusia seperti berdoa, makan bersama (Kenduri), proses pelaksanaan, dan sebagainya.

Bagi masyarakat Kerinci, kenduri sko (pesta panen) merupakan kebiasaan dari para leluhur terdahulu sebagai wujud rasa 
syukur atas hasil panen yang melimpah. Walaupun memakan biaya yang cukup besar, masyarakat tidak merasa keberatan karena dalam melalui kenduri inilah mereka dapat mengungkap rasa syukur mereka kepada roh-roh leluhur mereka terdahulu. Maka dari itulah kenduri ini akan tetap hidup dan akan dilanjutkan oleh generasi selanjutnya.

Upacara Kenduri Sko adalah ungkapan rasa syukur kepada Allah SWT yang telah memberikan rizki dan memohon untuk dilipatgandakan pendapatan mereka lewat hasil panen padi untuk tahun yang akan datang. Upacara ini selain memberi manfaat terhadap masyarakat Kerinci untuk menambah rasa syukur kepada Tuhan Yang Maha Esa juga memberikan pengaruh dalam bidang sosial, yang mana Kenduri Sko memberikan pengaruh pada adanya ikatan sosial yang terjalin antara masya rakat.

Secara sosiologis menurut fitrahnya manusia adalah makhluk yang suka hidup berkelompok dengan pengertian bahwa manusia dalam hidupnya senantiasa memerlukan bantuan orang lain. Untuk itulah kemudian manusia selain sebagai makhluk individu, manusia juga makhluk sosial. Terdorong oleh kedudukannya yang kodrati sebagai makhluk sosial maka manusia tidak dapat hidup seorang diri. Durkheim menyebutnya dengan istilah solidaritas sosial, yang terbagi atas solidaritas mekanik dan solidaritas organik. Ciri khas yang penting dari solidaritas mekanik adalah bahwa solidaritas itu didasarkan pada suatu tingkat homogenitas yang tinggi dalam kepercayaan, sentiment, dan sebagainya. Homogenitas serupa itu hanya mungkin kalau pembagian kerja bersifat sangat minim. Berlawanan dengan itu, solidaritas organik muncul karena pembagian kerja bertambah besar. Solidaritas itu didasarkan pada tingkat saling ketergantungan yang tinggi (Koenjaraning rat, 1972:76).

Secara terminologi kata "solidaritas" berasal dari bahasa latin "solidus". Kata ini di pakai dalam sistem sosial yang berhubungan dengan integritas kemasyara katan melalui kerja sama dan keterlibatan yang satu dengan yang lainnya (Elian, Jurnal Antropologi : Isu-Isu Sosial Budaya. Jilid 18 Terbitan 2 hal. 135-150). Bentuk dari solidaritas dalam kehidupan masyarakat berimplikasi pada kekompakan dan keterikatan bagian-bagian yang ada. Sebagaimana dalam upacara Kenduri Sko, dimulai dari persiapan rapat adat (musya warah) untuk menetapkan waktu pelaksanaan, pembagian tugas oleh masing-masing tokoh pelaksana ataupun peran ikut serta masyarakat dalam upacara semuanya ini menuntut adanya solidaritas sosial yang utuh dan kuat diantara para tokoh adat setempat dan masyarakat pada umumnya. Sehingga hal ini akan memini malisir terjadinya konflik atau pertengkaran antar individu.

\section{Pengaruh Pelaksanaan Kenduri Sko Terhadap Kepercayaan Masyarakat}

Mayoritas masyarakat Kerinci telah menganut agama Islam. Meskipun telah menganut agama Islam, masyarakat masih melaksanakan Kenduri Sko ini sebagai wujud rasa syukur dan terima kasih kepada roh-roh leluhur yang senantiasa memberikan hasil panen yang melimpah. Masyarakat masih meyakini pelaksanaan kenduri sko ini memiliki makna tersendiri yang apabila tidak dilaksanakan maka mereka akan mendapat musibah ataupun gagal panen.

Dalam bidang agama, upacara kenduri Sko memberi pengaruh pada kehidupan kerukunan umat khususnya masyarakat Kerinci yang beragama Islam. Dimana Islam mengajarkan untuk saling tolong menolong dan memupuk rasa persaudaraan antar sesamanya.

\section{Pengaruh Pelaksanaan Kenduri Sko Terhadap Perekonomian Masyarakat}

Pelaksanaan Kenduri Sko ternyata dapat mempengaruhi perekonomian dan penda patan daerah Kerinci. Hal ini tidak hanya dibuktikan pada saat upacara pelaksanaan kenduri sko saja tetapi dapat ditunjukkan dalam kehidupan sehari-hari.

Kalau dahulunya Kenduri sko hanya disaksikan oleh kerabat, teman ataupun rekan kerja, saat ini kenduri sko juga sangat sering dihadiri oleh para wisatawan dari luar 
daerah, bahkan mancanegara. Kenduri sko telah menarik perhatian para turis akan adanya rangkaian-rangkaian acara unik yang dilaksanakan oleh masyarakat. Hal ini tentunya akan sangat menguntungkan bagi masyarakat. Walaupun kegiatan ini menghabiskan biaya yang cukup besar, pada sisi lain kenduri sko juga meningkatkan minat para wisatawan untuk datang ke Kerinci. Dengan banyaknya para wisatawan yang datang, hal ini telah meningkatkan dan mengembangkan wisata daerah Kerinci, baik itu wisata alam ataupun wisata budayanya.

\section{Makna Yang Terkandung Dalam Pe laksanaan Kenduri Sko}

Geertz mengemukakan bahwa kebuda yaan merupakan suatu pola makna yang ditafsirkan/ diteruskan secara historis yang terwujud dalam bentuk-bentuk simbolik, dimana melalui bentuk-bentuk tersebut manusia berkomunikasi, melestariakan dan mengembangkan pengetahuan mereka tentang kehidupan dan bersikap tentang kehidupan (Geertz, 1992:82). Geertz meng gambarkan kebudayaan sebagi susunan arti yang dibawa simbol, tempat orang meneruskan pengetahuan mereka tentang keidupan dan mengekspresikan sikap. Kenduri Sko bagi masyarakat Kerinci me miliki makna berawal dari penafsirannya terhadap kebudayaannya yang tercermin dalam berbagai aktivitas yang mereka lakukan. Norma, nilai adat, kebiasaan dan tradisi masyarakat saat ini merupakan hasil penciptaan oleh generasi sebelumnya, kemudian diberlakukan dan dipertahankan secara turun temurun.

Kenduri Sko yang dilakukan oleh masyarakat merupakan representasi pola dari (model of) sebagai wujud dari tindakan yang dilakukan setelah panen padi, sedangkan makna dan nilai-nilai yang terkandung di dalam Kenduri Sko dan diyakini oleh masyarakat setempat merupakan representasi pola bagi (model for) yang digunakan untuk menginter pretasikan, mendorong, dan menciptakan tindakan atau dalam pengertian lain sebagai pedoman tindakan. Kenduri Sko yang dilakukan oleh masyarakat Kerinci bukanlah sesuatu yang baru. Kenduri Sko merupakan suatu kebiasaan yang telah lama hidup dan dan menjadi tradisi di mana masyarakat mendefenisikan dunianya, menyatakan perasaan dan memberikan penilaianpenilaian, serta memaknai tindakan-tinda kan yang dilakukannya.

Kenduri Sko pada hakekatnya bermakna memohon keselamatan kepada Tuhan Yang Maha Kuasa dan juga kepada roh nenek moyang, roh para leluhurnya, agar diberi rezeki yang melimpah, karena setelah kegiatan kenduri sko ini penduduk setempat akan kembali ke sawah dan ladang. Bagi masyarakat suku Kerinci upacara tradisi adat ini sangat penting dilaksanakan sebagai rasa syukur atas segenap rahmat dan karunia yang telah diberikan Allah SWT kepada mereka, dan lazimnya dalam rangkaian upacara adat/tradisi kenduri sko dilaksanakan acara penobatan para pemang ku-pemangku adat yang akan mengarah anak kemenakan/masyarakat adat yang ada di lingkungan luhah dan kalbu masingmasing.

Upacara adat kenduri sko yang dilaksanakan dihadiri segenap anak jantan dan anak betino baik yang berada di dusun maupun yang berada di perantauan. Bagi masyarakat suku Kerinci Kenduri Sko merupakan upacara adat terbesar yang ada di Kerinci dan mempunyai makna tersendiri bagi masyarakat. Adanya hubungan antara anak cucu dengan roh-roh nenek moyang yang terjalin melalui diadakannya Tarei Asyeik pada malam harinya. Setiap aktivitas yang dilakukan dalam Kenduri Sko dapat dipahami melalui interpretasi. Dengan interpretasi dapat ditemukan makna dari aktivitas tersebut. Dalam proses kegiatan Kenduri Sko mempunyai simbol yang diinterpretasikan, dan dari simbol tersebut dapat diketahui maknanya.

\section{KESIMPULAN}

$\mathrm{K}$ enduri Sko merupakan kenduri adat yang terdiri dari beberapa rangkaian kegiatan yang menghabiskan waktu 3-4 hari diantaranya pergelaran seni budaya, penobatan gelar adat, pembersihan benda-benda pusaka dan syukuran atas

DOI: 10.25077/jantro.v20.n1.p71-83.2018

JANTRO ISSN: 2355-5963 (Online)

under Lisensi Creative Commons Atribusi-BerbagiSerupa 4.0 Internasional 
hasil panen yang melimpah. Waktu pelaksanaan setiap desa akan berbedabeda sesuai dengan kesepakatan yang telah dimusyawarahkan bersama. Rang kaian kegiatan dilaksanakan mulai dari persiapan tempat, perlengkapan, dan makanan untuk mendoa. Pelaksanaan di awali dengan dengan syukuran (mendo'a) dimana adanya tamu atau anggota kerabat yang diundang mereka dapat mengunjungi setiap rumah dengan waktu yang berbeda untuk menikmati hidangan yang telah dihidangkan. Pada malam harinya, akan diadakan acara tarei asyeik dimana roh-roh leluhur diundang dalam rangkan pem bersihan benda-benda pusaka dari beberapa generasi. Pada hari yang ketiga, akan diadakan prosesi penobatan gelargelar adat kepada tokoh-tokoh yang telah disepakati setiap keluarga.

Kenduri Sko sebagai ungkapan rasa syukur kepada Allah SWT yang telah memberikan rizki dan memohon untuk dilipatgandakan pendapatan mereka lewat hasil panen padi untuk tahun yang akan datang. Upacara ini selain memberi manfaat terhadap masyarakat Kerinci untuk menambah rasa syukur kepada Tuhan Yang Maha Esa juga memberikan pengaruh dalam bidang sosial, yang mana Kenduri Sko memberikan pengaruh pada adanya ikatan sosial yang terjalin antara masyarakat. Masyarakat masih meyakini pelaksanaan kenduri sko ini memiliki makna tersendiri yang apabila tidak dilaksanakan maka mereka akan mendapat musibah ataupun gagal panen. Dalam bidang agama, upacara kenduri Sko memberi pengaruh pada kehidupan kerukunan umat khususnya masyarakat Kerinci yang beragama Islam. Pelaksanaan Kenduri Sko juga mempe ngaruhi perekonomian dan pendapatan daerah Kerinci. Kalau dahulunya Kenduri sko hanya disaksikan oleh kerabat, teman ataupun rekan kerja, saat ini kenduri sko juga sangat sering dihadiri oleh para wisatawan dari luar daerah, bahkan mancanegara. Kenduri sko telah menarik perhatian para turis akan adanya rangkaianrangkaian acara unik yang dilaksanakan oleh masyarakat. Hal ini tentunya akan sangat menguntungkan bagi masyarakat.

\section{E. UCAPAN TERIMA KASIH}

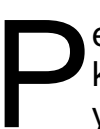
enulis mengucapkan terima kasih kepada Dirjen Kemenrisristek Dikti yang telah memberikan dukungan financial terhadap penelitian ini melalui Hibah Penelitian Dosen Pemula.

\section{Daftar Pustaka}

Agus, Bustanuddin. (2006). Agama Dalam Kehidupan Manusia (Pengantar Antropologi Agama). Jakarta : PT. Raja Grafindo Persada.

Alimin, dkk. (2006). Adat dan Budaya Daerah Kerinci. Dinas Kebudayaan Kabupaten Kerinci.

Benyamin. (2005). "Profil Kebudayaan Kerinci". [Internet]. Available From: (http/www.kerincikab.go.id) [Accesed 21 Juli 2017]

Dalmeda, M., \& Elian, N. (2017). Makna Tradisi Tabuik Oleh Masyarakat Kota Pariaman (Studi Deskriptif Interaksionisme Simbolik). Jurnal Antropologi: Isu-Isu Sosial Budaya, 18(2), 135-150. doi: https://doi.org/10.25077/jantro.v18.n2.p135-150.2016

Geertz, Clifford. (1992). Kebudayaan dan Agama. Yogyakarta: Kanisius. (1992). Tafsir Kebudayaan . Yogyakarta: Kanisius.

Haviland, A William. (1999). Antropologi . Jilid 2 Jakarta: Erlangga.

Johnson, Doyle Paul. (1990). Teori Sosiologi Klasik dan Modern, penerjemah Robert M.Z Lawang. Jakarta : PT Gramedia Pustaka Utama.

Kaplan, David, Albert A. Manners. (1999). Teori Budaya. Yogyakarta: Pustaka Pelajar. Koentjaraningrat. (1972). Beberapa Pokok Antropologi Sosial. Jakarta: Dian Rakyat.

Laira, Merlin. (2016). Upacara Mane'e Pada Masyarakat Kakorotan Kecamatan Nanusa Kabupaten Talaud. Jurnal Holistik. Tahun IX No. 18/ Juli 2016.

DOI: 10.25077/jantro.v20.n1.p71-83.2018

JANTRO ISSN: 2355-5963 (Online)

under Lisensi Creative Commons Atribusi-BerbagiSerupa 4.0 Internasional

82 | P a g e 
JURNAL ANTROPOLOGI: Isu-Isu Sosial Budaya. Juni 2018, Vol. 20 (1): 71-83

Online at http://jurnalantropologi.fisip.unand.ac.id/index.php/jantro

Liliweri, Alo. (2014). Pengantar Studi Kebudayaan. Bandung; Nusamedia

Miles, M B dan Huberman, A M. (1992). Analisis Data Kualitatif: Buku Sumber Tentang Metode-Metode Baru. Terjemahan oleh Tjetjep Rohendi Rohidi. Jakarta : Penerbit Universitas Indonesia (Ul-Press).

Nottingham, Elizabeth. (2002). Agama dan Masyarakat Suatu Pengantar Sosiologi Agama. Jakarta : PT. Raja Grafindo Persada.

Pals, L. Daniel. (2001). Sevent Teories Of Religion. Yogyakarta: Qalam.

Saefuddin, Achmat Fedyani. (2005). Antropologi Kontemporer. Jakarta: Kencana.

Sugiyono. (2008). Memahami Penelitian Kualitatif. Bandung: ALFABETA.

Zakaria, Iskandar. (1984). Tambo Sakti Alam kerinci. 